\title{
OPIS ZNISZCZENIA POLSKI LIANG QICHAO Z 1896 ROKU I NARODZINY POLSKIEGO TOPOSU W CHIŃSKIM DYSKURSIE REFORMISTYCZNYM
}

\section{Wstęp}

Potężne niegdyś imperium dynastii Qing, niekwestionowany wcześniej hegemon w regionie Azji Wschodniej i dużej części Azji wewnętrznej, w XIX w. zaczęło się chylić ku upadkowi. Narastające problemy wewnętrzne cesarstwa spotęgowała dodatkowo militarna i gospodarcza ekspansja mocarstw zachodnich, której pierwszymi aktami były wojny opiumowe. Dynastia Qing nie potrafiła skutecznie przeciwdziałać postępującemu osłabieniu własnej pozycji wraz z narzucaniem jej, począwszy od 1841 r., kolejnych traktatów, nazwanych później przez historyków nierównoprawnymi. Porażka w wojnie z Francją w latach 1884-1885 i dotkliwa klęska w starciu z bagatelizowaną wcześniej, lecz szybko modernizującą się Japonią w konflikcie z lat 1894-1895 doprowadziły do załamania prestiżu panującej dynastii i wzmocnienia się tendencji reformatorskich wśród części urzędniczego establishmentu. Dwie przegrane w ostatnich dekadach XIX w. wojny wykazały nieskuteczność wcześniejszych wysiłków części chińskich elit na rzecz wzmocnienia kraju w drodze selektywnego przyjmowania technologicznych rozwiązań zachodnich przy równoczesnym odrzuceniu ich intelektualnego i kulturowego podłoża. Kierujący się zasadą: „zachodnia nauka do użytku praktycznego, chińska nauka jako podstawa” (xixue wei yong, zhongxue wei ti) ruch „samoumocnienia” (ziqiang yundong), zapoczątkowany po drugiej wojnie opiumowej w 1861 r. i realizowany pod przywództwem takich urzędników konfucjanistów jak Li Hong- 
zhang (李鴻章, 1823-1901), w wyniku powyższych wydarzeń, a szczególnie klęski w wojnie z Japonią, utracił wiarygodność․

Porażkę ,samoumacniania” próbowała naprawić nowa generacja chińskich intelektualistów, postulująca odważniejsze reformy polityczno-społeczne i śmielej podchodząca do swoich zachodnich inspiracji. Reformatorzy nowego typu postulowali już nie tylko konieczność uczenia się zachodnich technologii, lecz również dogłębne studia nad zachodnimi kulturami, historią i ustrojami politycznymi. Wyróżniali się wśród nich pochodzący z Kantonu Kang Youwei (康有為, 1858-1927) oraz jego uczeń Liang Qichao (梁啟超, 1873-1929)².

Działalność reformatorów, takich jak Kang i Liang, zaowocowała powstaniem wielu tekstów, polemik i apeli do władz i doprowadziła do stworzenia nowego rodzaju dyskursu, nieobecnego wcześniej w Chinach. Stał się on w dużej mierze podglebiem późniejszych rewolucyjnych zmian, nie tylko politycznych, ale i kulturowo-społecznych. W odróżnieniu od hermetycznej i zapatrzonej w tradycję narracji wcześniejszych konfucjanistów nowe dyskusje niosły bogactwo informacji o świecie zewnętrznym. Autorzy wykorzystywali je do demaskowania przyczyn słabości państwa, dynastii i społeczeństwa oraz sięgali po wiele narzędzi retorycznych, odwołujących się do doświadczeń innych krajów, które miały stanowić pozytywny lub negatywny przykład dla Chin w ich drodze ku reformom oraz odbudowie pozycji i prestiżu. Działaniom tym towarzyszyło tworzenie nowego słownictwa, potrzebnego do opisu nieznanych wcześniej w literaturze chińskiej zjawisk, instytucji i procesów ${ }^{3}$.

Intelektualne związki łączące dużą część środowiska reformatorów powodowały, że idee oraz towarzyszące im neologizmy, powtarzane w kolejnych artykułach publikowanych w reformatorskich periodykach, szybko zdobywały popularność i zadomawiały się w powstającym nowym języku. Mimo niepowodzeń reformatorów, szybko zepchniętych do defensywy przez konserwatywny element w państwie, koncepcje stworzone przez nich w ostatnich latach panowania dynastii Qing zakorzeniły się na tyle głęboko, że ich rola w późniejszej historii Chin jest trud-

${ }^{1} \mathrm{~W}$ polskich badaniach sinologicznych obszerne omówienie ruchu samoumacniania w jego militarnym wymiarze można znaleźć w pracy Krzysztofa Gawlikowskiego, Chiny wobec Europy, Ossolineum, Wrocław 1979.

2 Szerzej o intelektualnym tle tych postulatów oraz o ich późniejszych konsekwencjach i współczesnych konotacjach, nie tylko w Chinach, patrz K. Gawlikowski, Procesy okcydentalizacji Chin oraz innych krajów Azji Wschodniej i ich stosunek do cywilizacji zachodniej, [w:] Adam Jelonek (red.), Wietnamczycy: system wartości, stereotypy Zachodu, Wydawnictwo Naukowe Scholar, Warszawa 2004, s. 26-86.

${ }^{3}$ Patrz Federico Masini, Formation of Modern Chinese Lexicon and Its Evolution Towards a National Language: The Period from 1840 to 1898, „Journal of Chinese Linguistics Monograph Series" 1993, nr 6. 
na do przecenienia. Dzięki pismom reformatorów chińskie elity zaczęły się uczyć nowego sposobu myślenia o świecie oraz o miejscu w nim ich kraju i cywilizacji. Choć z czasem kolejne pokolenia chińskich intelektualistów znalazły inne inspiracje i wypracowały odrębne koncepcje rozwiązania chińskich problemów, spychając umiarkowanych reformatorów, takich jak Kang i Liang, w cień, to wciąż w sensie intelektualnym pozostawały ich „dłużnikami”. Pisma tych dwóch autorów i ich środowiska były najczęściej pierwszymi źródłami wiedzy o świecie zewnętrznym dla przyszłych rewolucjonistów oraz uczyły ich krytycznego podejścia do własnej tradycji i kultury.

W inicjowanej przez Kanga i Lianga dyskusji o problemach Chin i świata, która rozgorzała na przełomie wieków, ważną rolę odgrywały historie „państw upadłych” lub „martwych” (wangguo 亡國). Były to państwa, które przestały istnieć z powodu braku reform, indolencji swoich elit i agresji zewnętrznej. Miały być zatem negatywnymi punktami odniesienia dla Chin, umoralniającymi przykładami tragicznych konsekwencji upartego trwania przy źle pojmowanej tradycji i odmawiania dostosowania się do zmieniającego się świata. Obok takich krajów, jak: Indie, Annam, Korea, Filipiny i Hawaje, szczególne miejsce w tym dyskursie zajęła Polska ${ }^{4}$. Rozbiory Rzeczypospolitej stały się szczególnie przemawiającym do wyobraźni wykształconych Chińczyków przykładem przerażających konsekwencji braku reform.

Przekazując swoim czytelnikom wiedzę o upadłych i skolonizowanych krajach oraz ich tragicznych doświadczeniach, autorzy przyczyniali się do nowego postrzegania miejsca Chin na świecie. Państwo Środka było w nim już tylko jednym z wielu elementów skomplikowanego systemu międzynarodowego, a nie jego „środkiem”. Choć oczywiście dla Chin najważniejszymi punktami odniesienia na arenie światowej były mocarstwa, z których ekspansją zmagały się na swoim terytorium, to reformistyczny dyskurs pomógł zadomowić się w świadomości chińskiej również państwom i narodom, z którymi Chińczycy nie mieli wcale kontaktu lub mieli go wyłącznie w marginalnym zakresie. Przyczyniło się to do powstania w Chinach, jak określiła to amerykańska badaczka Rebecca E. Karl, „świadomości nowej globalności"s.

Uświadomienie sobie tej globalności, będące efektem nowej wiedzy o geografii, geopolityce i historii innych państw i regionów, nie tylko umożliwiło zredefiniowanie miejsca Chin w świecie, ale i zrodziło chiński nacjonalizm. W ramach tego nurtu Chiny były państwem narodowym, a nie uniwersalistyczną cywiliza-

\footnotetext{
${ }^{4}$ Rebecca E. Karl, Staging the World. Chinese Nationalism at the Turn of the Twentieth Century, Duke University Press, Durham 2002.

${ }^{5}$ Ibidem, s. 10-12.
} 
cją, jak przyjmowano od wieków w konfucjańskim kulturalizmie ${ }^{6}$.,Świadomość globalności" i nacjonalizm, zjawiska zrodzone poza Chinami, łatwiej zadomowiły się w chińskiej umysłowości dzięki wykorzystaniu do ich tłumaczenia przykładów suwerennych dawniej państw skolonizowanych i zdominowanych przez imperializm. Stało się tak, ponieważ chińscy intelektualiści uznali, że to właśnie w tych przestrzeniach najwyraźniej i najostrzej objawiały się w ówczesnym świecie związki między „globalną nierównością” państw i nowoczesnością, pomiędzy nacjonalizmem i rewolucją, a także pomiędzy polityką i zmianami społecznymi?

Choć motyw rozbiorów Rzeczypospolitej funkcjonował intensywnie od przełomu XIX i XX w. aż do upadku cesarstwa w 1911 r. - do czego szczególnie przyczynił się memoriał Kang Youweia pt. Zapis o podziale i zniszczeniu Polski (Bolan fenmie ji 波蘭分滅記), złożony u tronu cesarskiego w 1898 r. w trakcie tzw. stu dni reform - ze względu na ograniczenia objętości niniejszego artykułu omówiony zostanie tu wyłącznie najważniejszy tekst w języku chińskim opisujący historię Polski, powstały wcześniej. Jest nim przełomowy esej Liang Qichao z sierpnia 1896 r., zapoczątkowujący szerokie zainteresowanie qingowskich elit historią rozbiorów Polski. Przełomowość tekstu Lianga polegała na „odkryciu analogii” między położeniem Rzeczypospolitej w przededniu rozbiorów i bieżącą sytuacją cesarstwa oraz nadaniu dziejom Rzeczypospolitej dydaktycznej wartości, niedostrzeganych przez wcześniejszych autorów chińskich kompendiów wiedzy o świecie zachodnim. Choć tekst Lianga był oparty w dużej mierze na obszernych cytatach z dostępnych już wcześniej źródeł, dopiero ten autor przekształcił motyw rozbiorów Polski w czytelną aluzję do obecnej sytuacji cesarstwa i wykorzystał ją w polemice politycznej. Równie istotnym czynnikiem, co odkrycie tej analo-

${ }^{6}$ Rozróżnienie między klasycznym konfucjańskim kulturalizmem a nowoczesnym chińskim nacjonalizmem, który miał go zastąpić w wyniku przemian polityczno-kulturowych zachodzących w Chinach na przełomie XIX i XX w., wprowadził do studiów nad chińską historią w latach 50. XX w. Joseph Levenson. Według Levensona tradycyjne elity konfucjańskie uważały swoją bazującą na konfucjańskich propozycjach moralno-etycznych wizję świata (tianxia) za uniwersalną i zdolną do przyciągania krajów i kultur spoza obszaru pierwotnego oddziaływania cywilizacji chińskiej samą mocą przykładu moralnego. W tej interpretacji przynależność do chińskiego porządku świata i lojalność wobec jego politycznych instytucji (guo) pochodziła z uznania go za moralnie lepszy, a nie z cech biologicznych i wrodzonych, takich jak etniczność czy rasa. To przekonanie o moralnej wyższości kultury chińskiej zostało zniszczone w wyniku ekspansji europejskich potęg i zachodniego darwinizmu społecznego. Inną zasadniczą zmianą, jaką wprowadzał do chińskiej świadomości nacjonalizm, było przeniesienie identyfikacji jednostki z szerszą wspólnotą narodową, której jednostka winna była bronić. Zmiana ta nadała rangę jednostce, która we wcześniejszym chińskim kulturalizmie była podporządkowana rodzinie uważanej za podmiot stosunków społecznych. Dziękuję za tę uwagę prof. Krzysztofowi Gawlikowskiemu. Patrz Joseph Levenson, Confucian China and Its Modern Fate, t. 1: The Problem of Intellectual Continuity, University of California Press, Berkeley-Los Angeles 1968, s. 98-108.

7 R.E. Karl, Staging the World..., s. 10. 
gii było jej upublicznienie na łamach nowego medium - wzorowanego na periodykach zachodnich czasopisma adresowanego do intelektualnych elit cesarstwa. Chcąc opisać szerzej intelektualny i historyczny kontekst, w którym w chińskiej publicystyce pojawił się ,polski topos”, przedstawiono tu skrótowo niektóre informacje dotyczące biografii Lianga oraz pisma, na łamach którego spopularyzował on ten wątek ${ }^{8}$.

\section{Liang Qichao - wczesna działalność i narodziny publicysty}

Wydaje się bardzo prawdopodobne, że pierwszym chińskim autorem, który dostrzegł w rozbiorach Rzeczypospolitej przestrogę dla swojego kraju, był Liang Qichao. Spostrzeżenie to zawarł w eseju Opis zniszczenia Polski (Bolan miewang $j i$ 波蘭滅亡記), który ukazał się 29 sierpnia 1896 r. w trzecim numerze szanghajskiego pisma „Shiwu Bao” (,Sprawy Bieżące” 時務報). Przed dokładniejszą analizą treści eseju warto się zatrzymać nad biografią jego autora i okolicznościami, w których 23-letni Liang zainteresował się historią rozbiorów Polski.

Liang Qichao urodził się w lutym 1873 r. w pobliżu Kantonu, w rodzinie rolniczej ceniącej tradycyjną edukację konfucjańskąa . Miał opinię wybitnie uzdolnionego już od wczesnego dzieciństwa; pierwszy stopień konfucjański xiucai, przyznawany na poziomie prefektury, zdobył w wieku 11 lat, a prowincjonalny tytuł juren uzyskał, mając zaledwie 16 lat. Być może ze względu na swoje niekonwencjonalne już wówczas poglądy Liang nie zdał w 1890 r. egzaminu na najwyższy stołeczny stopień jinshi (którego nie udało mu się już nigdy zdobyć). W drodze powrotnej do Kantonu z nieudanych egzaminów w stolicy Liang zatrzymał się w Szanghaju, gdzie po raz pierwszy zobaczył mapę świata i miał okazję zetknąc się z pracami autorów zachodnich przetłumaczonymi na język chiński. Kontakt z tymi nowymi źródłami wiedzy zapoczątkował przemianę tradycyjnie wykształconego chiń-

${ }^{8}$ Topos Polski nie był jedynym, który ukształtował się w Chinach w tej epoce. Innym często opisywanym punktem odniesienia była osmańska Turcja, „chory człowiek Europy”, w której smutnym losie upadającego imperium chińscy postępowi intelektualiści widzieli przestrogę i lustrzane odbicie najnowszych dziejów swojego państwa - „chorego człowieka Azji”. Podobnie jak w przypadku Polski o wadze i sile przykładu Turcji dla wysiłków reformatorskich tego okresu świadczył fakt, że Kang Youwei jeden ze swoich pięciu memoriałów w 1898 r. poświęcił Turcji - Tujue Xueruo $J i$ [Zapis o osłabieniu Turcji].

9 Ojciec Lianga samodzielnie kształcił go od szóstego roku życia w zakresie kanonu konfucjańskiego, jego dziadek zaś był posiadaczem najniższego tytułu konfucjańskiego xiucai. J.R. Levenson, Liang Ch 'i-Ch' ao and the Mind of Modern China, Harvard University Press, Cambridge 1953, s. $15-16$. 
skiego nastolatka w nowatorskiego uczonego poszukującego wiedzy o świecie zewnętrznym, świadomego ograniczeń konserwatywnego chińskiego światopoglądu ${ }^{10}$.

W latach 1891-1894 Liang pobierał naukę w założonej w Kantonie przez Kang Youweia prywatnej szkole, w której oprócz osobistej wizji konfucjanizmu Kanga nauczano również kontroli ciała, spraw zagranicznych oraz spraw bieżących. Z uwagi na zainteresowanie Kanga buddyzmem uczniowie szkoły w Kantonie poznawali również rozmaite aspekty tej religii ${ }^{11}$. W 1894 r. Liang przeniósł się do Pekinu, gdzie towarzyszył swojemu nauczycielowi w działalności na rzecz reform w państwie. Po klęsce w wojnie z Japonią Kang i Liang zmobilizowali 1300 kandydatów na stopień jinshi przebywających w Pekinie do złożenia oficjalnego sprzeciwu wobec warunków traktatu z Shimonoseki. Liang, jako reprezentant obecnych w stolicy 190 urzędników konfucjanistów z Kantonu, złożył wówczas również własny memoriał do cesarza, podsumowujący trudną sytuację kraju. Był ponadto jednym z trzech tysięcy studentów, którzy pod przewodnictwem Kanga wystąpili do tronu o rozpoczęcie reform ${ }^{12}$.

Latem 1895 r. Kang i Liang, odgrywający już role nieformalnych przywódców środowiska reformatorsko usposobionych uczonych konfucjańskich, przejęli przywództwo w powołanym z ich inspiracji w Pekinie Towarzystwie Studiów nad Potęgą (Qiangxuehui 强學會), organizacją skupiającą urzędników i intelektualistów o postępowych zapatrywaniach i mającą oddziały w kilku miastach ${ }^{13}$. Towarzystwo wzywało do podjęcia reform systemu politycznego, które miały doprowadzić do odbudowy potęgi kraju. Pod tym względem jego główne zadanie było zbieżne z postulatami ruchu samoumocnienia, choć członkowie Qiangxuehui, i wielu innych podobnych mu organizacji, uważali, że droga ta powinna prowadzić poprzez studia nad zachodnią kulturą, kształtowanie opinii publicznej i walkę o ,prawa publiczne" (minquan) ${ }^{14}$. Liang został sekretarzem centralnego oddziału pekińskiego Qiangxuehui.

Qiangxuehui cieszyło się poparciem nie tylko postępowych chińskich urzędników i intelektualistów - w tym czołowych postaci samoumocnienia: Li Hongzhanga, Zhang Zhidonga (張之洞, 1837-1909), a także Yuan Shikaia (袁世凱, 1859-1916), który przekazał pewne sumy na jego funkcjonowanie - ale i licznego grona cudzoziemskich sympatyków, szczególnie protestanckich misjonarzy

${ }^{10}$ Tang Xiaobing, Global Space and the Nationalist Discourse of Modernity: The Historical Thinking of Liang Qichao, Stanford University Press, Stanford 1996, s. 2.

11 J.R. Levenson, Liang Ch'i-Ch'ao ..., s. 18.

12 Ibidem, s. 18-19.

13 Stowarzyszenie miało oddziały w Hankou, Szanghaju, Nankinie, Wuchangu i Tianjinie. Ibidem, s. 20.

${ }_{14}$ Prasenjit Duara, Rescuing History from the Nation. Questioning Narratives of Modern China, The University of Chicago Press, Chicago 1995, s. 157. 
z Towarzystwa Propagacji Wiedzy Chrześcijańskiej i Ogólnej wśród Chińczyków (Society for the Diffusion of Christian and General Knowledge Among the Chinese - SDK), posługującego się chińską nazwą Guangxuehui (廣學會). SDK prowadziło intensywną działalność prasową, wydając liczne chińskojęzyczne tytuły, z najpopularniejszą gazetą „Wanguo Gongbao” (angielski tytuł „The Globe Magazine" ${ }^{15}$. Pismo to cieszyło się zainteresowaniem chińskich czytelników do tego stopnia, że Qiangxuehui swój organ prasowy, którego redaktorami byli Kang i Liang, nazwało tak samo, a większość miejsca $\mathrm{w}$ nim poświęcało na przedruki artykułów z oryginalnego tytułu ${ }^{16}$.

Wśród członków SDK-Guangxuehui szczególnie mocno zaangażowany w sprawę chińskich reform był Timothy Richard (1845-1919), mający szerokie kontakty na dworze cesarskim walijski baptysta i od $1891 \mathrm{r}$. sekretarz SDK ${ }^{17}$. Według biografa Lianga Josepha Levensona młody Kantończyk miał w tym okresie przez pewien czas pełnić obowiązki chińskiego sekretarza Richarda, choć ten nie wspomina o tym w autobiografii ${ }^{18}$. Liang utrzymywał jednak z pewnością regularne kontakty z Richardem, co miało wpływ na dalszy rozwój jego wiedzy o świecie. Richard odegrał również rolę w kształtowaniu Lianga jako publicysty, dziennikarza i wydawcy czasopism, namawiając go do zaprzestania przedruków z „Wanguo Gongbao" i utworzenia niezależnego periodyku Qiangxuehui ${ }^{19}$. W ten sposób Liang stanął na czele nowego tytułu „Zhong-Wai Jiwen” („Wiadomości z Chin i Zagranicy"), publikującego wiadomości krajowe i zagraniczne oraz jego codzienny reformistyczny esej ${ }^{20}$. Choć pismo zostało zamknięte przez władze qingowskie już w styczniu 1896 r. (a samo Qiangxuehui wiosną tego samego roku), Liang zdobył niezbędne doświadczenie dziennikarskie i publicystyczne oraz przekonał się o publicznej sile oddziaływania nowoczesnej prasy.

Swoje nowo rozbudzone ambicje publicystyczne Liang mógł realizować w Szanghaju, dokąd bezpośrednio po likwidacji „Zhong-Wai Jiwen” zaprosił go inny Kantończyk, Huang Zunxian (黃遵憲, 1848-1905), wpływowy qingowski dyplomata, japonista i jeden ze współtwórców Qiangxuehui. Huang za namową Kang Youweia

${ }^{15}$ SDK nie było organizacją skupiającą wyłącznie misjonarzy, lecz to właśnie oni nadawali ton jego działalności. Hao Chang, Intellectual Change and the Reform Movement, 1890-8, [w:] John King Fairbank, Kwang-Ching Liu (red.), Cambridge History of China, t. 11: Late Ch'ing, part 2, Cambridge University Press, Cambridge 2006, s. 278.

16 J.R. Levenson, Liang Ch'i-Ch'ao..., s. 21.

17 Hao Chang, Intellectual Change..., s. 278.

18 J.R. Levenson, Liang Ch'i-Ch'ao..., s. 18. Patrz też Timothy Richard, Forty-Five Years in China. Reminiscences, Frederick A. Stokes Company, New York 1916.

19 J.R. Levenson, Liang Ch'i-Ch'ao..., s. 21.

${ }^{20}$ Ibidem. „Zhong-Wai Jiwen” było pekińskim organem prasowym Qiangxuehui. Oddział szanghajski organizacji publikował własne pismo „Qiangxue Bao”. 
planował propagowanie programu reform w nowym periodyku ${ }^{21}$. Liang przybył do Szanghaju na przełomie kwietnia i maja 1896 r., by rozpocząć pracę nad stworzeniem czasopisma pod kuratelą Huanga i Wang Kangniana (汪康年, 1860-1911), doradcy Zhang Zhidonga, jednego z najbardziej wpływowych urzędników w cesarstwie i czołowej postaci ruchu samoumocnienia, najpotężniejszego człowieka na południu kraju ${ }^{22}$. To właśnie Zhang, pełniący od końca 1895 r. funkcję generalnego gubernatora Hunanu i Hubei, był głównym sponsorem powstania pisma, finansując je ze środków pozyskanych z podległych mu kopalni w Hunanie ${ }^{23}$. Pismo stanowiło część rozbudowanej prywatnej administracji Zhanga, będąc przedłużeniem powołanego przez niego w Wuchangu biura tłumaczeń Hubei (Hubei Yishuju $)^{24}$. Dużą część redakcji stanowili thumacze zatrudniani przez Zhanga w biurze tłumaczeń oraz jego prywatni sekretarze. W zamyśle Zhanga pismo miało pełnić funkcję służebną wobec wysiłków modernizacyjnych cesarstwa, publikując głównie starannie dobrane tłumaczenia tekstów zagranicznych, zgodne z konserwatywną linią polityczną swojego protektora, i unikać otwarcie politycznych tekstów odredakcyjnych ${ }^{25}$.

Nowy periodyk „Shiwu Bao”, znany również pod angielskim tytułem „The Chinese Progress", miał premierę 9 sierpnia 1896 r. Liang został mianowany na stanowisko redaktora naczelnego, a Huang Zunxian objął funkcję dyrektora generalnego spółki wydawniczej. Pismo, którego redakcja znajdowała się na terenie koncesji brytyjskiej w Szanghaju, ukazywało się co 10 dni przez kolejne dwa lata i pomogło Liangowi zdobyć ogólnokrajową renomę ${ }^{26}$. Dzięki jego tekstom „Shiwu Bao" niemal natychmiast stało się jednym z najchętniej czytanych czasopism w kraju, a jego popularności sprzyjały najwyższy wśród reformistycznej prasy nakład oraz najbardziej rozbudowany system dystrybucji ${ }^{27}$.

21 Ibidem, s. 21.

22 Ouyang Hong, Zhang Zhidong yu ,, Shiwu Bao” [Zhang Zhidong i ,Shiwu Bao”], ,Zhongshan Daxue Yanjiusheng Xuekan - Shehui Kexue ban” (,Journal of the Graduates of the Sun Yat-sen University. Social Sciences") 2000, t. 21, nr 4, s. 86-97.

${ }^{23}$ Seungjoo Yoon, Literati-Journalists of the Chinese Progress (Shiwu Bao) in Discord, 1896-1898, [w:] R.E. Karl, Peter G. Zarrow (red.), Rethinking the 1898 Reform Period: Political and Cultural Change in Late Qing China, Harvard University Asia Center, Cambridge Mass. 2002, s. 50-53.

${ }^{24}$ Ibidem, s. 52.

25 Ibidem, s. 53.

26 J.R. Levenson, Liang Ch'i-Ch'ao..., s. 22.

27 Początkowo nakład pisma wynosił 4 tys. egzemplarzy, po roku wzrósł do 12 tys., a w okresie największej popularności liczył 17 tys. He Bingran, Liang Qichao he „Shiwu Bao” de Bianfa Xuanchuan Tese [Liang Qichao i specyfika propagandy reform w „Shiwu Bao”], „Xinwen Yanjiu Ziliao” 1990, nr 1, s. 175. Umiejscowienie redakcji i spółki wydawniczej „Shiwu Bao” w Szanghaju ułatwiało dystrybucję dzięki roli miasta jako głównego portu rzecznego i morskiego kraju, skąd towary transportowano najszybciej do Tianjinu i Pekinu na północy, Kantonu na południu oraz Wuchangu 
Zaproszenie przez Huang Zunxiana do pracy w „Shiwu Bao” Lianga, a wraz z nim licznych zwolenników Kang Youweia pochodzących z prowincji Guangdong, zasiało jednak od samego początku ziarna wewnętrznego konfliktu w redakcji. Miał on charakter zarówno animozji regionalnej, stawiając naprzeciw siebie Kantończyków i resztę zespołu, w dużej części wywodzącą się z prowincji Zhejiang, jak i sporu ideologicznego ${ }^{28}$. Od samego początku prac nad powołaniem „Shiwu Bao” trwała również polemika między Zhangiem i Wang Kangnianem z jednej strony, preferującymi oparcie treści pisma głównie na tłumaczeniach zachodnich tekstów prasowych, a Liangiem, pragnącym przekształcić „Shiwu Bao” w forum publicystyki politycznej ${ }^{29}$. Podejmowane przez Lianga i jego zwolenników próby przemycenia do publikowanych na łamach gazety tekstów idei reformatorskich niejednokrotnie doprowadzały później do ostrych reakcji władz cesarskich, uczonych ze stołecznej akademii Hanlin i samego Zhang Zhidonga ${ }^{30}$. Kantończycy musieli więc często maskować swoje poglądy oraz łagodzić sformułowania i metafory. Jednak to odważne poglądy „frakcji kantońskiej” w redakcji „Shiwu Bao” przyczyniały się do popularności gazety.

Choć zatrudnieni w „Shiwu Bao” autorzy, tacy jak Liang Qichao, nie mieli zamiaru pozwolić narzucić sobie ścisłych ograniczeń przewidzianych przez Zhanga i odgrywać służebnej roli tłumaczy zagranicznych tekstów dla jego administracji, pismo nie było adresowane do szerokich mas czytelniczych. Grupę odbiorców stanowili raczej członkowie wykształconych elit, ludzie dobrze zaznajomieni z konfucjańską nauką i podzielający postępowe przekonania publicystów. Członkowie tej najwyższej i najbardziej wyrafinowanej kulturowo warstwy społecznej mieli się stać pierwszą grupą, do której trafiała myśl reformatorska i od której miało się rozpocząć „oświecenie ludu” (minzhi) ${ }^{31}$.

\footnotetext{
i Syczuanu w interiorze. Z czasem pismo i jego spółka wydawnicza stały się tak wpływowe, że udzielały innym publikacjom wsparcia finansowego i logistycznego. Jiang Hong, , Shiwu Bao” zai Weixin Baokan zhong de Jiaose Fenxi [Analiza roli „Shiwu Bao” wśród innych czasopism reformatorskich], ,Xinwen Chuang” („News Window”) 2010, nr 1, s. 118.

${ }^{28}$ Seungjoo Yoon, Literati-Journalists..., s. 56.

${ }^{29}$ He Bingran, Liang Qichao he „, Shiwu Bao”..., s. 173.

30 Seungjoo Yoon, Literati-Journalists..., s. 57.

${ }^{31}$ Ibidem, s. 53-54. Szerzej o czytelnikach „Shiwu Bao” i ich zróżnicowaniu patrz Pan Guangzhe, ,, Shiwu Bao” he tade duzhe [„Shiwu Bao” i jego czytelnicy], „Lishi Yanjiu” („Historical Research") 2005, nr 5, s. 60-83.
} 


\section{Opis zniszczenia Polski. Odnalezienie analogii}

W pierwszym numerze „Shiwu Bao” Liang opublikował artykuł O korzyściach z prasy dla spraw państwowych (Lun baoguan youyi yu guoshi), będący manifestem jego przekonań o politycznej i społecznej roli dziennikarstwa. W tekście zakreślił również ramy programowe nowego pisma. Pierwszy punkt głosił, że najważniejszym celem „Shiwu Bao” jest „upowszechnianie [informacji o] i wyjaśnianie wydarzeń w świecie, tak aby czytelnik miał wiedzę o sytuacji globalnej i rozumiał przyczyny siły, potęgi, słabości i upadku"32. Jednym z pierwszych tekstów realizujących to zadanie opublikowanych przez Lianga stał się esej o dziejowych doświadczeniach Polski. Inspiracją do jego napisania były przeczytane niedawno nowo dostępne źródła wiedzy o świecie zachodnim, a zainteresowanie dziejami Polski stanowiło pochodną lektury prac poświęconych historii Rosji.

Dla Lianga lata 1894-1896 były bowiem okresem nie tylko zdobywania doświadczeń publicystycznych i wydawniczych, ale również dalszego poszerzania horyzontów intelektualnych i wiedzy o świecie. W tym samym 1896 r. Liang przeczytał m.in. Ewolucję i etykę Thomasa Huxleya w roboczym chińskim przekładzie Yan Fu (嚴復, 1854-1921), głównego interpretatora zachodniej myśli i kreatora chińskich odpowiedników wielu ważnych zachodnich pojęćc ${ }^{33}$. Dzieło Huxleya, którego tytuł Yan przełożył jako Teoria ewolucji (Tianyanlun), tworząc przy tym pierwsze chińskie słowo odnoszące się do koncepcji ewolucji - tianyan (tj. zmiany wymuszone/zadecydowane przez niebo), zaszczepiło w Liangu zainteresowanie społecznym darwinizmem i przekonało go o słuszności założeń tej doktryny. Swojej wierze w darwinizm społeczny Liang dawał wyraz w późniejszych tekstach, takich jak Nowa historiografia z 1902 r., w którym argumentował, że historia Chin, tak samo jak wszystkich innych krajów, jest progresywna i ewolucyjna ${ }^{34}$. W okresie rodzącego się zainteresowania Lianga teoriami społecznego darwinizmu i wynikającego z nich przekonania, że ,przetrwa najlepiej dostosowany”35, przy-

${ }^{32}$ He Bingran, Liang Qichao he „Shiwu Bao”..., s. 176.

${ }^{3}$ Don Krasher Price, Russia and the Roots of the Chinese Revolution, 1896-1911, Harvard University Press, Cambridge Mass. 1974, s. 23. Yan pod pseudonimem opublikował w „Shiwu Bao” kilka artykułów. Patrz Seungjoo Yoon, Literati-Journalists..., s. 58-59.

${ }^{34}$ Timothy Brook, Capitalism and the Writing of Modern History in China, [w:] T. Brook, Gregory Blue (red.), China and Historical Capitalism. Genealogies of Sinological Knowledge, Cambridge University Press, Cambridge 1999, s. 124.

35 To sformułowanie Herberta Spencera Yan Fu przełożył na chiński jako wujing tianze, shizhe shengcun - „byty rywalizują i z wyboru nieba/natury przeżywa [najlepiej] dostosowany”. Więcej o problematyczności przekładu koncepcji natury jako tian - niebo i dylematach Yan Fu patrz Benjamin Schwartz, In Search of Wealth and Power: Yen Fu and the West, Belknap Press of Harvard University Press, Cambridge Mass. 1964, s. 96. 
kład rozbiorów Polski przez silniejsze mocarstwa pomógł mu ugruntować wiarę, że zasada ta sprawdza się również w świecie państw i polityki międzynarodowej ${ }^{36}$.

Oprócz wcześniejszych źródeł w języku chińskim, zawierających dość ograniczone informacje o historii Polski, takich jak Atlas i opisy państw zamorskich (Haiguo Tuzhi) Wei Yuana (魏源, 1794-1857) z 1842 r., w swoich studiach nad rozbiorami Rzeczypospolitej Liang dysponował nowszymi pozycjami, obecnymi od niedawna na chińskim rynku ${ }^{37}$. Dokonał wyboru źródła opisującego losy Polski ze współczuciem, choć jego osobiste koneksje wskazywałyby raczej na pracę surowo i bez empatii opisującą historyczne doświadczenia Polaków.

W czasie wojny z Japonią w latach 1894-1895 zaprzyjaźniony z Liangiem Timothy Richard opublikował chińskie tłumaczenie popularnonaukowej pracy stosunkowo mało znanego szkockiego autora Roberta Mackenziego (1823-1881) The 19th Century. A History ${ }^{38}$. Tłumaczenie to, którego chiński tytuł brzmiał Taixi xinshi lanyao [Niezbędne podstawy dla zrozumienia nowej historii Zachodu], dokonane przez Richarda wspólnie z jego chińskim współpracownikiem, redaktorem „Wanguo Gongbao” Cai Erkangiem (蔡爾康, 1852-192?), cieszyło się ogromną popularnością i sprzedało się w olbrzymim jak na ówczesne warunki nakładzie kilkudziesięciu tysięcy sztuk ${ }^{39}$. W napisanym przez siebie wstępie Richard wskazywał na powody dotychczasowych porażek Chin w konfrontacji z Zachodem: „,niepraktykowanie woli nieba/woli bożej (buti tianxin), brak harmonii w stosunkach z innymi państwami (buhe yiguo), brak szacunku dla ludzi wybitnych (bujing shanren)"

Wprawdzie praca Mackenziego była wyraźnie anglo- i frankocentryczna, zawierała jednak kilkanaście wzmianek o Polsce, omówiono w niej m.in. kwestię polską na kongresie wiedeńskim. Stosunek Mackenziego do losów Polski i Polaków pozbawiony był jednak empatii. W jego ocenie to Polska przez większość dziejów była agresorem wobec Rosji, a Polacy nie przedstawiali sobą większej warto-

${ }^{36}$ Lektury dzieła Huxleya oraz innych prac tłumaczonych przez Yana na klasyczny język chiński, m.in. Zasady socjologii Herberta Spencera, tak mocno rzutowały na dalszy rozwój intelektualny Lianga, że niektórzy badacze uznają, iż Yan Fu wywarł większy wpływ na jego kształtowanie jako myśliciela niż Kang Youwei. Ibidem, s. 82-83.

${ }^{37}$ Praca Wei Yuana i inne wczesne źródła chińskie zawierające wiedzę o historii Polski omówione zostaną w odrębnym artykule.

38 Początkowo fragmenty przekładu ukazywały się w częściach na łamach „Wanguo Gongbao”, a ich wielka popularność wśród czytelników skłoniła SDK do wydania całości w formie książkowej. Zhang Xiantao, The Origins of the Modern Chinese Press. The Influence of the Protestant Missionary Press in Late Qing China, Routledge, New York 2007, s. 59.

${ }^{39}$ Richard szacuje w swoich wspomnieniach, że w sumie książkę wydano w milionie egzemplarzy, w samym Hangzhou naliczył sześć ,„pirackich” edycji, zarówno luksusowych, adresowanych do zamożnych czytelników, jak i w wersji dla uboższych. T. Richard, Forty-Five Years in China ..., s. 232.

${ }^{40}$ Cyt. za Liu Yajun, Li Timotai yu 'Taixi Xinshi Lanyao'de Yijie [Przekład i wstęp Timothy'ego Richarda do Taixi Xinshi Lanyao], „Hebei Shifan Daxue Xuebao”, listopad 2004, t. 27, nr 6, s. 121. 
ści i sami ponosili winę za swój los: „,[..] w czasie rozbiorów Polacy znajdowali się w stanie największego zwyrodnienia - ignoranccy, leniwi, biedni, pijani, niegospodarni" ${ }^{41}$. Według brytyjskiego autora w ostatecznym rozrachunku rosyjskie rządy w Polsce (przedstawiał on bowiem rozbiory przede wszystkim jako dzieło Rosji) przyniosły krajowi cywilizacyjny postęp i szansę na rozwój, której nie miał w okresie samodzielności ${ }^{42}$.

Nieprzychylne Polsce poglądy Szkota, niezłagodzone w chińskim przekładzie, nie padły jednak w Chinach na podatny grunt ${ }^{43}$. Choć tłumaczenie Richarda i Caia mogło posłużyć do celów propagandy reform, wskazując na pozytywne efekty zmian wprowadzonych przez Piotra Wielkiego w Rosji, dzięki którym pognębiła ona wcześniejszego agresora, w ,polskim eseju” Lianga nie ma śladu negatywnego stosunku autora do Polski. Być może jedną z przyczyn, dla których moralizujące oceny polskich wad i skontrastowanych z nimi rosyjskich zalet zawarte w Taixi xinshi lanyao nie zdobyły w Chinach popularności, był fakt, że w latach 90. XIX w. rosnąca część chińskich elit z coraz większą podejrzliwością patrzyła na postępowanie Rosji, dopatrując się w tym mocarstwie największego zagrożenia dla Chin ${ }^{44}$. Również sugerowana przez Mackenziego cywilizująca rola mocarstw, wprowadzających siłą postęp i rozwój w zacofanych krajach niezdolnych do samodzielnego życia, nie mogła wywołać entuzjazmu wielu intelektualistów zatroskanych o przyszłość cesarstwa, takich jak Liang.

Pisząc tekst o ,zniszczeniu Polski”, Liang nie wykorzystał zatem pracy przetłumaczonej przez zaprzyjaźnionego misjonarza i chińskiego uczonego, lecz oparł swoją wiedzę o tych wydarzeniach na informacjach zawartych w innej książce, przełożonej przez inną parę tłumaczy. Dziełem tym była dwutomowa monograficzna historia Rosji pt. History of Russia autorstwa angielskiego historyka i dziennikarza Waltera K. Kelly’ego (zm. 1867), przełożona na chiński przez brytyjskiego misjonarza metodystę Fredericka Galpina ${ }^{45}$ oraz jego chińskiego współpracownika Xu Jingluo (徐景羅) i wydana, bez podania tytułu i autora pracy oryginalnej, przez jedną z misjonarskich organizacji edukacyjnych w roku $1887^{46}$. Chiński przekład

${ }^{41}$ Robert Mackenzie, The 19th Century. A History, T. Nelson and Sons, Edinburgh 1880, s. 879.

${ }^{42}$ Ibidem.

${ }^{43}$ Patrz Taixi Xinshi Lanyao, Shanghai Shudian Chubanshe, Shanghai 2002, s. 336.

44 D.C. Price, Russia and the Roots..., s. 67-81.

${ }^{45}$ Galpin był misjonarzem United Methodist Free Church w prowincji Zhejiang. Patrz Rolf G. Tiedemann, Reference Guide to Christian Missionary Societies in China, M.E. Sharpe, New York 2009, s. 229.

${ }^{46}$ Pracę wydała po raz pierwszy misjonarska organizacja The School and Text Book Series Committee, która zleciła autorom ,przygotowanie nie tłumaczenia, ale oryginalnej pracy, opartej na najlepszej dostępnej książce zagranicznej”, dostosowanej do chińskich zwyczajów, manier i literackich przyzwyczajeń. Dodatkowym wymogiem było, by praca ta ,w sposób szczególnie mocny oddziaływała na Chińczyków”. Być może wymóg jedynie oparcia się na pracy zagranicznej, a nie jej bezpo- 
tej pracy pt. E shi jiyi [Poprawione tłumaczenie historii Rosji] cieszył się dużą popularnością wśród chińskich intelektualistów, bardzo zainteresowanych potężnym sąsiadem, a szczególnie reformami Piotra Wielkiego, o których praca ta informowała najszerzej spośród opracowań dostępnych w Chinach ${ }^{47}$. Liang Qichao wysoko oceniał jej merytoryczną wartość, polecając ją jako najlepszą historię obcego kraju dostępną w $\mathrm{Chinach}^{48}$. Praca zawierała również najobszerniejsze informacje o historii Polski dostępne w języku chińskim; w drugim tomie dzieła Kelly’ego sprawom Polski autor poświęcił cztery całe rozdziały oraz część dwóch innych ${ }^{49}$. Tak szerokie omówienie problematyki polskiej mogło być najważniejszą z przyczyn, dla których to dzieło Kelly’ego, Galpina i Xu stało się dla Lianga podstawą do napisania ,polskiego eseju”.

Choć Liang oparł Opis zniszczenia Polski w dużej części na tłumaczeniu Galpina i $\mathrm{Xu}$, nie podał jednak swojego źródła. Liczący około 1300 znaków tekst rozpoczął od omówienia dramatycznych wydarzeń towarzyszących stłumieniu przez Rosjan powstania listopadowego i „ponownego zniszczenia Polski” (Bolan zai wang yu $E$ ye $)^{50}$, tj. znacznego ograniczenia autonomii Królestwa Polskiego $\mathrm{w}$ roku $1832^{51}$. Warstwa faktograficzna eseju jest w większości zaczerpnięta bezpośrednio od Galpina i $\mathrm{Xu}^{52}$.

Pierwsze akapity stanowią niemal w całości dosłowny cytat z rozdziału 68. E shi jiyi, zatytułowanego Opis rosyjskich okrucieństw wyrzadzonych polskim wygnańcom, kościołowi grecko-katolickiemu i mniszkom, który z kolei był obszernym i wiernym oryginałowi przekładem rozdziału LXVIII pracy Kelly'ego ${ }^{53}$. Przedstawiając prześladowania polskiej ludności przez Rosjan, Liang wybrał najbardziej przemawiające do wyobraźni fragmenty pracy Kelly’ego/Galpina i Xu, dodając

średniego tłumaczenia, był powodem, dla którego Galpin i Xu ukrywali informację o pierwowzorze swojego dzieła. Identyfikacji oryginalnej podstawy dzieła Galpina i Xu dokonał dzięki łutowi szczęścia Don Price. D.C. Price, Russia and the Roots..., s. 34, 232, przyp. 26 i 27.

${ }^{47}$ Ibidem, s. 34.

48 Ibidem.

49 Dziejom Polski poświęcone były rozdziały XL (Affairs of Poland), XLII (First Partition of Poland), LXII (Failure of Alexander's Experiment in Poland), LXVII (The Insurrection of Poland) i LXVIII (Cruelties Inflicted on the Poles) w tomie 2.

${ }^{50} \mathrm{~W}$ trakcie pracy nad niniejszym artykułem korzystano z tekstu Bolan miewang ji w wielkim zbiorze prac Liang Qichao Yinbingshi heji - Zhuanji [Dzieła zebrane z Pijalni Lodu - Zbiór esejów], t. 1, poz. 14, s. 1-3 (1527-1529), Zhonghua Shuju, Shanghai 1936.

${ }^{51}$ Liang Qichao, Bolan miewang ji.

${ }^{52} \mathrm{~W}$ trakcie pracy korzystano z egzemplarza $E$ shi jiyi w czterech tomach (juan) z 14. roku panowania cesarza Guangxu (1888), ze zbiorów biblioteki miejskiej w Nankinie. Według wiedzy autora było to najnowsze wydanie dostępne w 1896 r. Kan Feidi (Frederick Galpin), E shi jiyi, brak wydawcy, wydanie powielaczowe.

${ }^{53}$ Patrz W. Kelly, The History of Russia ..., t. 2, s. 376-392. 
jedynie krótkie komentarze, podkreślające okropność opisywanych scen. Ponad trzy czwarte dwóch pierwszych kolumn tekstu zajmuje następujący cytat z $E s h i$ jiyi: Wszystkich spiskowców [...] zesłano pod straża na Syberię i w góry Kaukazu. Zmuszono [ich] do stużby wojskowej. Przesiedlono 30 tys. Polaków na Kaukaz, by rekultywowali nieużytki (kaiken huangwu). Nie pozwolono im zabrać ze soba członków rodzin. Wszyscy ci ludzie byli szlachcicami, właścicielami ziemskimi, osobami zamożnymi i uczonymi (jueshen, fu jiwei shizhe) ${ }^{54}$. Dla wzmocnienia dramatycznej wymowy powyższego fragmentu Liang dodał od siebie: Niezliczone kibitki wypetniaty drogi. [Ludzie byli] jak owce popędzane przez psy. Obcy zajęli ich pola, a ich żony $i$ dzieci stały się niewolnikami i żebrakami ${ }^{55}$. Po krótkim fragmencie własnego komentarza Liang ponownie posłużył się bezpośrednim cytatem z E shi jiyi: W marcu 1830 r. rosyjski król (E wang) rozkazal, by każdy biedny i osierocony Polak powyżej siódmego roku życia zostat przesiedlony na tereny pograniczne. Początkowo dzieci łapano w nocy, później również w biały dzień. 17 maja tegoż roku sznur dlugich wozów wypetniono niezliczonymi dziećmi, które wywieziono pod straża na Syberię. Po kołach tych wozów wspinali się rozpaczajacy rodzice, chcac jechać z nimi. Żotnierze okrutnie ich bili, raniąc, zrzucajac na ziemię $i$ wpychajac pod wozy, by ginęli zmiażḋeni kołami ${ }^{56}$.

Wśród napiętnowanych szczególnie mocno przez Kelly'ego represji wymierzonych w polskie aspiracje narodowe Liang wyróżnił w swoim tekście politykę ograniczania swobód językowych, ponownie posługując się dosłownym cytatem z Galpina i Xu, dodając jedynie dość znaczące własne podkreślenie: [...] a nawet zakazano uczonym i ludowi mówić po polsku i nakazano im uczyć sie języka Rosjan. W akademiach i szkołach wszyscy ucza się rosyjskiego. Pewnego razu grupa studentów zebrała się potajemnie w Wilnie, by dyskutować po polsku, lecz zostali aresztowani przez policję i ukarani za popetnienie ciężkiego przestępstwa ${ }^{57}$.

Po opisach okrucieństw popełnianych przez władze carskie na ludności pokonanego kraju Liang cofnął swoją narrację do okresu świetności Polski, pisząc, że była ona w wiekach XVII i XVIII jedna z europejskich potęg, lecz później ze względu na brak wewnętrznych reform politycznych [wszyscy] od władcy po zwykty lud

${ }^{54}$ Liang Qichao, Bolan miewang ji. Patrz Kan Feidi, E shi Jimi, di 68 zhang (rozdz. 68), 4 juan.

55 Liang Qichao, Bolan miewang ji, s. 1.

${ }^{56}$ Ibidem. Patrz też Kan Feidi, E shi jiyi.

${ }^{57}$ Ibidem. Patrz też Kan Feidi, E shi jiyi oraz W. Kelly, The History of Russia ..., t. 2, s. 377-378. W tym cytacie z jakiegoś powodu Liang opuścił dramatyczny opis Kelly’ego, wiernie przełożony przez Galpina i Xu, aresztowanych studentów przywiązanych przez Kozaków do siodeł i wleczonych w dal. W przytoczonym cytacie z $E$ shi jiyi Liang zignorował wyjaśnienie, że celem zakazu używania polszczyzny było sprawienie, by „Polacy nie myśleli nawet o swoim dawnym państwie” (shi Boren buzhi you guguo zhi si). 
przyzwyczaili się do słabości i lenistwa ${ }^{58}$. Decyzja, by artykuł rozpocząć od opisu krwawych represji z lat 1830-1832, a przyczyny tej sytuacji analizować w drugiej kolejności, była podyktowana zapewne chęcią nadania tekstowi większego dramatyzmu i wzmocnienia jego dydaktycznej wymowy. Wśród czytelników „Shiwu Bao", zaalarmowanych słabnącą pozycją państwa qingowskiego, opisy postępującego rozkładu i trwonienia potęgi dawnej Rzeczypospolitej miały wywołać oczywiste skojarzenia, a celowo dramatycznie przedstawiona relacja o represjach popowstaniowych - wysłać jasne ostrzeżenie i wzmocnić nastrój moralnej paniki. „Brak wewnętrznych reform politycznych”, jak pokazywał przykład Polski, prowadzi zatem w prostej linii do upadku państwa, zagrożenia egzystencji jego ludu i kultury w najbardziej podstawowym wymiarze - języka i edukacji.

Analiza tekstu Lianga i sposobu wykorzystania przez niego przekładu Galpina i Xu nasuwa przypuszczenia, że szczególnie mocno przemawiały do niego opisy represji wymierzonych w wykształcone polskie elity; wśród wysiedlanych pod przymusem na rubieże rosyjskiego imperium wymienia on bowiem, w przytoczonym już wyżej cytacie, „szlachciców, właścicieli ziemskich, osoby zamożne oraz uczonych", zmieniając tym samym wymowę oryginalnego tekstu i ignorując dalszą część zdania w E shi jiyi. W przekładzie Galpina i Xu mowa jest bowiem o społecznym przekroju wygnańców, wśród których wielu było przedstawicieli wymienionych grup (qi zhong duo quan jueshen), co Liang przeformułował na „wszyscy ci ludzie byli szlachcicami" (qi ren jie quan jueshen), pomijając całkowicie dalszą część cytowanego zdania wymieniającego wśród wywożonych również „chłopów, robotników i kupców"59. Pytanie, czy klasowa nieścisłość cytowania przez Lianga dostępnego mu źródła wynikała ze świadomego wyboru, podyktowanego koniecznością politycznej agitacji przedstawicieli chińskich elit, czy z niedoskonałości posiadanej przez niego kopii E shi jiyi, pozostanie zapewne tymczasowo bez odpowiedzi.

Niezależnie jednak od różnic między cytowanym dziełem i esejem Lianga słownictwo $E$ shi jiyi wkradło się wraz z obszernymi cytatami do Bolan miewang $j i$ i słownika jego autora. Wśród szeroko wykorzystywanych przez Galpina i Xu określeń powtórzonych przez Lianga wyjątkowo często powtarzało się słowo min - lud, w kontekście imperium qingowskiego używane z reguły w znaczeniu „ludu poddanego cesarzowi”, „niewolników cesarza”. Posługując się takimi zaczerpniętymi z E shi jiyi określeniami jak Bomin - Polacy, lud Polski, Liang przyczynił się do wykreowania obrazu wydarzeń w Polsce jako masowych, usprawiedliwionych moralnie wystąpień ludowych, a nie jedynie politycznej walki elit.

\footnotetext{
${ }^{58}$ Liang Qichao, Bolan miewang ji, s. 1.

${ }^{59}$ Patrz Kan Feidi, E shi jiyi.
} 
Rzeczywista wartość artykułu Lianga leżała w fakcie dostrzeżenia przez niego analogii pomiędzy opisywanymi przez Kelly'ego wydarzeniami sprzed wieku i bieżącą sytuacją polityczną cesarstwa. Choć E shi jiyi cieszyła się stosunkowo dużą popularnością wśród wykształconych elit, problematyka polska nie przyciągnęła wcześniej, jak się wydaje, szczególnej uwagi chińskich czytelników. Wysoki nakład i szeroka dystrybucja „Shiwu Bao” pomogły rozpowszechnić wiedzę o pouczających losach Rzeczypospolitej wśród intelektualnych elit późnoqingowskich Chin. Niechęć przedrozbiorowych elit do reform łączyła się z ich podatnością na korupcję, co było ledwie zawoalowaną krytyką stanu urzędniczego w cesarstwie, ze znanymi również w Chinach konsekwencjami: $Z$ powodu korupcji i indolencji urzędników i ministrów lud znalazł się w chaosie i powstało ogólne przerażenie. [...] Sfery publiczna i prywatna wpadty w pogtębiajace się z każdym dniem ubóstwo. W 1763 r. Rosja poleciła swojemu ambasadorowi w Polsce Keyserlingowi, by wydał ogromne kwoty na łapówki dla Polaków, dzięki którym wielu ministrów polskiego dworu [zaczęło] sprzyjać Rosji, a nawet ponad połowa zwyklych ludzi (baixing) [zaczęła] z nadzieja patrzeć na Rosję $e^{60}$.

W dalszej części tekstu Liang powtarza za Galpinem i Xu wiadomości o polskiej wojnie domowej w 1764 r., w wyniku której doszło do koronacji Stanisława Augusta Poniatowskiego na króla Polski (choć ponownie powiela błąd tłumaczy, umiejscawiając te wydarzenia w 1765 r.). Konflikt ten przedstawiony został w E shi jiyi jako „rebelia ludu Polski” (Boguo min luan), w wyniku czego „błagano Rosję o interwencję wojskową" (qi bing yu E) ${ }^{61}$. Rosja, wykorzystując pretekst, wkroczyła do Polski, ,paląc i popełniając wielkie okrucieństwa" ${ }^{2}$. W przededniu pierwszego rozbioru słabość Rzeczypospolitej, wedle cytowanych przez Lianga słów Galpina i Xu, ,osiągnęła stan krytyczny, a wszyscy ministrowie dworu posłuszni byli rozkazom Rosji”'63.

Ostatnie dekady istnienia Rzeczypospolitej Liang opisał zwięźle, ponownie cytując fragmenty z tekstu E shi jiyi: W 1772 r. Rosja, Austria i Prusy podpisaty traktat, dzielac [między siebie] Polskę. Rosja zyskała 19,8 tysięcy li kwadratowych, Austria zyskata 13,5 tysięcy li kwadratowych, a Prusy 6300 li kwadratowych. Zmuszono polskiego króla do oddania ziemi i błagania o pokój. Pozostało jedynie 42 tysiace li kwadratowych ziemi. Tylko Turcja sprzeciwiła się [temu] zgodnie z zasada powstrzymywania silniejszego i wspierania stabszego, [lecz] wkrótce została pokonana przez Rosję. Państwa Europy baty się potęgi Rosji. Wszystkie $w$ strachu dbaty o wtasne bezpieczeństwo $i$ żadne nie angażowato się $w$ sprawe

\footnotetext{
${ }^{60}$ Liang Qichao, Bolan miewang ji, s. 1.

${ }^{61}$ Ibidem, patrz też Kan Feidi, E shi Jimi, di 40 zhang [rozdz. 40].

${ }^{62}$ Ibidem, patrz też Kan Feidi, E shi jiy, di 40 zhang [rozdz. 40].

${ }^{63}$ Liang Qichao, Bolan miewang ji, s. 2.
} 
Polski. W 1789 r. w czasie tajnych negocjacji dwory Rosji i Prus porozumiaty się co do swojej woli szybkiego zniszczenia Polski, chcac uwolnić się od problemów [wywoływanych przez] pozostałych [Polaków]. W (17)9364 roku 80 tysięcy żotnierzy runęło na granice Polski. Niski ranga polski oficer Kościuszko (Gesijiwusuo) [stanął na czele] powstania przeciw Rosji. Po jego porażce ratowat się ucieczka do Włoch ${ }^{65}$. W 1795 r. Rosja, Austria i Prusy ponownie podzielity terytorium Polski i zmusity polskiego króla do abdykacji, obiecując mu 200 tysięcy sztuk srebra rocznie na utrzymanie, a dtugi urzędników spłacają w rekompensacie. Zniszczenie Polski dokonało się $e^{66}$.

W eseju znalazły się również informacje o późniejszych losach ziem polskich: powołaniu przez Napoleona Księstwa Warszawskiego i otwarciu parlamentu Królestwa Polskiego przez cara Aleksandra w 1818 r., oraz o powstaniach z lat 1830-1832 i 1863-1865. W przypadku powstania styczniowego Liang nie przytoczył jednak żadnych informacji - te nie były wówczas szerzej opisane w żadnym z dostępnych opracowań w języku chińskich.

Faktograficzna warstwa tekstu Lianga była zatem wtórna w stosunku do $E$ shi jiyi. Liang w sposób czytelny akcentował jednak istotne dla chińskich elit skojarzenia i lekcje płynące z historycznych doświadczeń Polski. Mimo że nie identyfikował swoich źródeł (podobnie jak nie robili tego Galpin i Xu), to takie postępowanie mieściło się w popularyzatorskiej roli jego tekstu, typowej dla publikacji w ówczesnej chińskiej prasie. Najważniejszym być może aspektem opublikowania eseju Lianga był sam fakt, że dokonano tego na łamach przełomowego medium - nowoczesnego pisma, docierającego do wielkiej (jak na ówczesne warunki) liczby czytelników i będącego forpocztą modernizmu. Istotna rola, jaką odegrała prasa w procesach kształtowania tożsamości narodowej w Chinach, umiejscawia esej Lianga blisko źródeł nowoczesnej chińskiej samoświadomości, skupionej wokół państwa narodowego, które na skutek działalności m.in. Lianga miało się narodzić 15 lat później.

Powtarzając w formie dosłownej sformułowania Xu, którego rozumienie europejskich i rosyjskich uwarunkowań kulturowych oraz politycznych było bardzo ograniczone, Liang przejmował jego język opisu największego upadku państwa w nowożytnych dziejach Zachodu. Ograniczenia thumacza powodowały, że w opisanych wydarzeniach trudno dopatrywać się wiernego przekazu wiedzy o historii

${ }^{64}$ To kolejny błąd w datowaniu Lianga, powtórzony przez niego za Galpinem i Xu - powstanie miało miejsce w 1794 r., choć w 1793 r. Tadeusz Kościuszko działał już jako emisariusz poza granicami Rzeczypospolitej.

${ }^{65}$ Informacja błędna-Kościuszko dostał się do rosyjskiej niewoli, skąd został wypuszczony po wiernopoddańczej deklaracji i wyjechał do Francji, a potem do Szwajcarii.

${ }^{66}$ Liang Qichao, Bolan miewang ji, s. 2. 
Rosji, Polski i innych państw. Jest to raczej parafraza, znaczona miejscami błędami i sprzecznymi z angielskim oryginałem Kelly'ego osądami, zrozumiałymi jednak dla czytelników żyjących w świecie tradycyjnych, ale ulegających gwałtownym przemianom chińskich wartości. Niewymieniony z imienia w E shi jiyi król Polski nie odpowiada wiernie swojemu pierwowzorowi - zawiłości XVIII-wiecznej europejskiej polityki i kultury politycznej Rzeczypospolitej umykały Xu. Rzeczpospolita u schyłku swojej potęgi przypomina w jego ujęciu raczej cesarstwo qingowskie z końca XIX w., z cesarzem otoczonym skorumpowanymi i nieudolnymi urzędnikami. Opisy wewnętrznych „rebelii ludowych i wojskowych” również bardziej przypominają qingowskie doświadczenia historyczne, gdy osłabione powstaniami tajpingów, muzułmanów i Nian cesarstwo stało się ofiarą obcych interwencji.

Wielka rola, jaką odegrał w procesie powstawania eseju Lianga tekst Galpina i Xu, każe widzieć w tych dwóch thumaczach istotnych autorów „odkrycia analogii” między dziejami Rzeczypospolitej a losami imperium qingowskiego. Szczególnie ważną postacią jest Xu Jingluo, który przełożył narrację historiograficzną Kelly'ego na zrozumiały dla wykształconych chińskich czytelników klasyczny ję$z \mathrm{yk}^{67}$. Popełnione przez niego błędy w przekładzie, będące efektem zarówno doświadczeń i światopoglądu wykształconego przedstawiciela konfucjańskich elit, choć nawróconego na protestanckie chrześcijaństwo, jak i trudności w komunikacji z Galpinem, uczyniły dzieje Rosji i Polski zrozumiałymi dla chińskiego odbiorcy. Być może zbyt dużym nadużyciem byłoby stwierdzenie, że bez pomyłek i nadinterpretacji terminologicznych Xu Liang nie dostrzegłby w dziejach Rzeczypospolitej lekcji dla swojego kraju, jednak z całą pewnością przekład to ułatwił, a język opisu tej analogii należy przypisać tłumaczowi.

Choć rozbiorów Polski dokonały trzy mocarstwa, Liang główny nacisk położył na przedstawienie działań Rosji. Tekst Bolan miewang ji wpisywał się w rosnący wśród chińskich elit nastrój podejrzliwości wobec Rosji i był częścią wzbierającego rusofobicznego nurtu publicystyki, konsekwentnie malującego obraz rosyjskich wysiłków na rzecz rozszerzenia swoich wpływów i zdominowania Chin, Dalekiego Wschodu i świata ${ }^{68}$. Działania Rosji miały być przejawem wcielania przez nią w życie tzw. testamentu Piotra Wielkiego, instruującego w 14 punktach o sposobach zdobycia dominacji nad światem na drodze podboju Bliskiego i Dalekiego Wschodu ${ }^{69}$. Tekst „testamentu”, będącego w istocie fałszerstwem, znalazł się

${ }^{67} \mathrm{~W}$ nim należy też widzieć głównego autora ostatecznej chińskiej wersji pracy Kelly’ego. Ze względu na swoje lingwistyczne ograniczenia Galpin nie monitorował ściśle postępów pracy swojego chińskiego współpracownika ani nie przejrzał zapewne uważnie rękopisu przekładu. Patrz D.C. Price, Russia and the Roots..., s. 35-36.

68 Ibidem, s. 72.

69 „Testament Piotra Wielkiego”, choć przez większość uczonych uważany za falsyfikat (Fiodor Dostojewski oskarżał o jego stworzenie Polaków), był wielokrotnie wykorzystywany w histo- 
również w E shi jiyi, przyczyniając się do uwiarygodnienia w oczach chińskich elit obaw przed rosyjskim ekspansjonizmem ${ }^{70}$.

Antyrosyjskie nastroje wzmacniały rozprzestrzeniające się od 1895 r. pogłoski o domniemanym podpisaniu przez władze qingowskie tajnego porozumienia z rosyjskim ambasadorem Arturem Cassinim (1836-1913) miałaby tzw. konwencji Cassiniego. „Konwencja” miała pozwolić Rosji na budowę linii kolejowych w Mandżurii, w tym do Port Arthur, przyznawać jej wyłączne prawa do eksploatacji kopalń w regionie oraz oddawać obszar Jiaozhou w Shandongu w 15-letnią dzierżawę ${ }^{71}$. Choć „konwencja” była kolejną fikcją, to informacje o niej aktywnie propagowała prasa misjonarska w rodzaju „Wanguo Gongbao”, a przedruki thumaczenia jej rzekomego tekstu w ciągu następnego roku ukazywały się w kilku chińskich czasopismach ${ }^{72}$.

Tekst Lianga był z jednej strony produktem panujących nastrojów, z drugiej pomagał je wzmocnić. Choć „testament Piotra Wielkiego” i „konwencja Cassiniego" były falsyfikatami, zagrożenie ze strony Rosji rzeczywiście istniało. Od czasu tzw. kryzysu Ili z lat 1879-1881, gdy Rosja odmawiała zwrotu zajętego w okresie powstań muzułmańskich regionu Ili w Turkiestanie Wschodnim, elity chińskie podejrzliwie patrzyły na rosyjskie zakusy. Wprawdzie Rosja zwróciła region po traktacie z Petersburga w 1881 r., lecz cesarstwo qingowskie opłaciło to kontrybucjami. Szczególny niepokój budziły rosyjskie posunięcia w regionie Mandżurii. Rosję prezentowano jako stanowiącą nie mniejsze zagrożenie niż Wielka Brytania czy Francja. Historia krajów takich jak Polska była przestrogą dla tych wśród chińskich elit, którzy w Rosji widzieli przeciwwagę dla zagrożeń brytyjskiego, francuskiego i japońskiego, a nawet kraj zaprzyjaźniony i sojuszniczy.

Liang przestrzegał, wskazując na przykład Polski, że „Rosja pożarła liczne kraje, tak jak połyka ofiarę wieloryb i jak zjada liść larwa jedwabnika"73. W przeci-

rii do pobudzania antyrosyjskich nastrojów. Jego mit narodził się w porewolucyjnej Francji. Przed wyprawą moskiewską Napoleona prasa francuska opisywała rzekomą treść „testamentu”. Polityka rosyjska miała być w istocie konsekwentną realizacją jego zapisów - zniszczenie Polski - „,bastionu cywilizacji” oraz późniejsze rosyjskie spiski w celu skłócenia państw europejskich - wszystkie te działania interpretowano jako elementy strategii przykazanej przez Piotra. W Chinach mit ,testamentu" okazał się bardzo żywotny. Jeszcze w 1980 r. po radzieckiej inwazji na Afganistan oficjalne źródła w Pekinie oskarżyły Związek Radziecki o działania wypływające z chęci wykonania „testamentu”. Albert Resis, Russophobia and the „, Testament” of Peter the Great, 1812-1980. „Slavic Review" 1985, t. 44, nr 4, s. 681-693.

70 D.C. Price, Russia and the Roots..., s. 72.

71 Ibidem, s. 70.

72 Ibidem.

${ }^{73}$ Liang Qichao, Bolan miewang ji, s. 2. Metafora Rosji „ogryzającej i pożerającej” (wyrażona w formie idiomatycznego wyrażenia chengyu ,jing tun can shi”) inne państwa pojawiła się wcześniej w tekście wybitnego tłumacza i publicysty Wang Tao (王鞱, 1828-1897) Ying yi bao Tu [An- 
wieństwie do Wielkiej Brytanii, Francji i innych potęg zagrażających cesarstwu nie osiągnęła tego wyłącznie na drodze podbojów militarnych, lecz przede wszystkim poprzez podstepy, [w których] wykorzystywała kwestie poszanowania religii [prawosławnej], [mieszane] matżeństwa [zawierane w celu] szpiegowania oraz opierajac się na [korumpowaniu] wpływowych dostojników, którzy zastraszaniem doprowadzaja do ruiny ludzi i państwa ${ }^{74}$. Oczywiście metody te okazywały się skuteczne wobec państw, których sytuacja wewnętrzna pozwalała na takie machinacje - Polska okazała się niezdolna do stawienia odporu Rosji, gdyż ,zaniedbała kwestię poprawy swojej polityki wewnętrznej, a jej długotrwała słabość osiągnęła wielkie rozmiary" ${ }^{\prime 75}$. Liang obawiał się, że tą drogą podążało imperium qingowskie, i wzywał do podjęcia środków mających zapobiec powtórzeniu tragicznego losu Polski. Dotychczasowe wysiłki ruchu samoumocnienia okazały się jednak niewystarczające, a naiwna wiara ,uczonych miłujących humanitarność” w to, że „nauka prawa międzynarodowego ( gongfa), w nadziei, że sprawiedliwość powstrzyma brutalną siłę i wspomoże słabych i małych" "76, prowadzi donikąd.

Liang w zdecydowany sposób skrytykował zwolenników oparcia polityki zagranicznej imperium na sojuszu z jednym z mocarstw, w tej roli część elit zazwyczaj widziała Rosję, wskazując na hipokryzję potęg i wybiórcze stosowanie przez nie przepisów prawa międzynarodowego: Widziatem, jak trzy kraje - Rosja, Prusy i Austria-podpisuja niemoralne porozumienie, wysyłaja wojska, jak szpieguja, by zyskać 240 tys. li ziemi, i dziela ja między siebie. Gdzie byli wtedy przywódcy innych krajów? Czy przestrzegali tzw. prawa międzynarodowego? Ci, którzy nie poszukuja samoumocnienia i chronia sie pod protekcje mocarstw, uciekaja się pod ochronę innych - tych niestety z pewnościa spotka rychte zniszczenie ${ }^{77}$.

Celem eseju Lianga było zatem w równym stopniu ostrzeżenie przed imperialistycznymi zakusami Rosji i przed konsekwencjami odmawiania reform. Chcąc uniknąć losu Polski, Chiny musiały podążyć śladami Szwecji i Danii, również zagrożonych przez Rosję, które „choć nie mają więcej ziemi i ludności niż Polska, to istnieją po dziś dzień" 78 . Liang argumentował w ten sposób reformy zmierzające w kierunku stworzenia monarchii konstytucyjnej. Brak zgody na podjęcie wysiłku modernizacyjnego byłby według Lianga politycznym samobójstwem, takim

\footnotetext{
glia powinna chronić Turcję]. Patrz http:/www.zdic.net/c/8/173/387717.htm [dostęp 10 lutego 2014]. W 1894 r. w pracy pt. Yong Shu powtórzył ją w tym kontekście qingowski urzędnik i ekonomista Chen Chi (1855-1900), prominentny członek Qiangxuehui, późniejszy pekiński korespondent „Shiwu Bao". D.C. Price, Russia and the Roots..., s. 67.

${ }^{74}$ Liang Qichao, Bolan miewang ji, s. 2.

75 Ibidem.

${ }^{76}$ Ibidem.

77 Ibidem, s. 3.

${ }^{78}$ Ibidem, s. 2.
} 
samym, jakie popełniła Polska, która „sama zadała sobie śmierć, a nie poniosła ją z rąk Rosji" ${ }^{\prime 79}$. Przetrwanie cesarstwa i Chin nabierało w interpretacji Lianga charakteru darwinowsko-spencerowskiej walki o przetrwanie najlepiej przystosowanego - w świecie stosunków międzynarodowych, gdzie prawo było jedynie zasłoną dla machinacji mocarstw, liczyło się tylko bezwzględne dążenie do efektywności państwa, nawet kosztem działań radykalnych: Jeśli do domostwa dostana sie lisy i myszy, trzeba oprzeć się na pomocy tygrysów i wilków [tj. trzeba być okrutnym i bezwzględnym], a nawet trzeba jeść tylko mięso [stać się drapieżnikiem] ${ }^{80}$.

Esej Lianga był jednym z licznych artykułów opublikowanych przez niego na łamach „Shiwu Bao”, propagujących koncepcję wprowadzenia w cesarstwie ustroju konstytucyjnego jako naturalnego, kolejnego etapu rozwoju państwa. Chiny i imperium qingowskie musiały się dostosować do bezwzględnych zasad dziejowego postępu lub podzielić los Polski.

\section{Zakończenie}

Intensyfikacja agresywnych działań mocarstw, począwszy od 1896 r., pomogła upowszechnić „odkrycie analogii” między historią rozbiorów Polski i współczesną sytuacją polityczną cesarstwa. Jeszcze w tym samym roku Rosja zagwarantowała sobie prawa do budowy linii kolejowej do Władywostoku przez tereny Mandżurii wraz z przywilejem eksterytorialności jej trasy i dzierżawy bazy morskiej w Port Artur na południu regionu. Tym samym spełniała się część „przepowiedni” fałszywej „konwencji Cassiniego”. Pod koniec 1897 r. Niemcy zajęły region Jiaozhou w Shandongu, rozpoczynając okres gorączkowej rywalizacji mocarstw o posiadłości w Chinach ${ }^{81}$.

Taki rozwój wypadków oraz publicystyczny talent Lianga spowodowały, że Polska na stałe weszła do repertuaru tematycznego poruszanego w chińskiej prasie. W samym „Shiwu Bao” jeszcze co najmniej dwukrotnie publikowano artykuły w całości poświęcone problematyce polskiej ${ }^{82}$. Do 1910 r. w prasie chińskiej opublikowano, według wyliczeń Feng Kexue przeprowadzonych na podstawie anali-

79 Ibidem.

80 Ibidem.

${ }^{81}$ W 1898 r. Wielka Brytania wydzierżawiła od cesarstwa qingowskiego port Weihaiwei po przeciwległej do Jiaozhou stronie Półwyspu Szantuńskiego na 25 lat. W tym samym roku Francja zagwarantowała sobie podobne przywileje na obszarze Guangzhouwan w prowincji Kanton.

${ }^{82}$ Feng Kexue, Bolan wangguo shi yu wanqing minzuzhuyi shuxie [Historia upadku państwa polskiego a pisarstwo nacjonalistyczne w okresie późnej dynastii Qing], praca magisterska obroniona w 2012 r. na kierunku etnologia, Uniwersytet Nankiński, s. 16. Dziękuję promotorowi pracy, panu profesorowi Hua Tao, za udostępnienie mi egzemplarza rozprawy. 
zy bibliografii nowożytnych czasopism chińskich zredagowanej przez Bibliotekę Szanghajską, co najmniej 21 artykułów o Polsce (w tytułach których występuje słowo Polska), również w prasie wychodzącej w interiorze kraju, m.in. w prowincji Henan $^{83}$. Według ustaleń tego autora w tym okresie opublikowano w różnych pismach w całym kraju także co najmniej 39 artykułów poruszających wątek polski. W przeanalizowanej przez niego liczbie pism artykuły te stanowiły $9,8 \%$ wszystkich publikowanych tekstów ${ }^{84}$. O wielkim powodzeniu wątku polskiego wśród chińskich elit może świadczyć fakt, że w 1904 r. jeden z reformatorów tradycyjnego teatru chińskiego Wang Xiaonong (汪笑侬, 1858-1918) opublikował libretto opery pt. Guazhong lanyin poświęconej fikcyjnemu rozbiorowi Polski dokonanemu przez Turcję (!). Operę tę wystawiono po raz pierwszy w tym samym roku w Szanghaju i stała się ona najbardziej dyskutowaną i docenianą operą nowego stylu w pierwszej dekadzie XX stulecia ${ }^{85}$.

W zbiorowej pamięci chińskich elit motyw Polski i rozbiorów Rzeczypospolitej umocnił się szczególnie dzięki memoriałowi Kang Youweia z 1898 r., adresowanemu bezpośrednio nie do inteligencji cesarstwa, ale do najważniejszego czytelnika w państwie - cesarza. Powielany w późniejszym okresie tekst memoriału stał się dla inteligenckiej warstwy chińskiego społeczeństwa dowodem ,nobilitacji" wątku polskiego w dyskursie modernizatorskim i reformatorskim. Do 1904 r. słowo Bolan stało się pełnoprawną częścią chińskiego słownictwa, zarówno jako rzeczownik, jak i w funkcji czasownika, oraz stałym elementem tekstów o współczesnym świecie i kryzysie Chin ${ }^{86}$. Jako czasownik bolan oznaczało podzielenie, rozbiór Chin i stało się niewymagającym dalszych objaśnień skrótem myślowym, toposem odnoszącym się do wiszącego nad cesarstwem zagrożenia ,polandyzacji”, o którym pisali niemal wszyscy XX-wieczni intelektualiści chińscy ${ }^{87}$.

${ }^{83}$ Ibidem, s. 16-18.

${ }^{84}$ Ibidem, s. 23.

${ }^{85}$ Szeroka analiza Guazhong lanyin oraz angielski przekład treści jedynego zachowanego w całości aktu I patrz R.E. Karl, Staging the World..., s. 35-49, 203-220.

${ }^{86}$ Ibidem, s. 33.

${ }^{87}$ Ibidem. 